\title{
The Effectiveness Of The Credit Relaxation Policy On The Batik MSMEs Affected By Covid-19 In Solo City
}

\author{
Edy Supriyono ${ }^{1)}$, Nurmadi Harsa Sumarta ${ }^{2)}$ \\ ${ }_{1,2}$ Universitas Sebelas Maret Surakarta \\ *Email correspondence: edyvision7@ gmail.com
}

\begin{abstract}
This research focuses on empirical analysis of the effect of credit relaxation policy on the sustainability of Batik MSMEs in Solo. This research is motivated by the negative impact of the spread of the Corona virus (Covid-19) pandemic on the economic sector in Solo, especially in the Batik MSMEs, which is one of the mainstay affected industries. A more in-depth study of the effectiveness and influence of this implementation on the sustainability of batikMSMEs in the city of Solo is needed, especially from the perspective of direct MSMEs. The design of this research is causality research with the object of batik UMKM in the administrative area of Surakarta City. The data used are primary data from questionnaires. Data analysis will be performed with Multiple Regression Analysis. With this research, it is hoped that there will be a contribution to increasing the effectiveness of the implementation of credit relaxation at MSMEs if there is a similar urgent situation.
\end{abstract}

Keywords: credit relaxation policy, the sustainability of MSMEs, the impact of the Corona Virus (Covid-19).

Citation Suggestions: Supriyono, E., \& Sumarta, N. H. (2021). The Effectiveness Of The Credit Relaxation Policy On The Batik MSMEs Affected By Covid-19 In Solo City. Jurnal Akuntansi dan Pajak, 21 (2), 450-460. doi:http://dx.doi.org/10.29040/jap.v21i2.1583

\section{DOI: http://dx.doi.org/10.29040/jap.v21i2.1583}

\section{INTRODUCTION}

The spread of the Corona virus pandemic (Covid19 ) in the world has reached a very severe stage. As a new type of disease that is easily transmitted, the number of victims who have fallen due to being infected with the Corona virus (Covid-19) is very large. According to data from John Hopkins University, as of April 26, 2020, there have been 2.8 million positive cases of being infected with the Corona virus (Covid-19) with the death toll reaching 203,043 , bringing the death rate to $7 \%$. The number of virus infectioncases is still increasing every day. Therefore, the Corona virus storm (Covid-19) has been declared a pandemic by the World Health Organization (WHO) (Cucinotta \& Vanelli, 2020). As a consequence, the majority of countries have flocked to establish social restriction policies for their people. In fact, not a few countries have implemented a total lockdown policy to break the chain of spreading this virus.

The policy of lockdown is not an easy way. This policy will be a difficult matter for a developing country, especially for countries with large populations like Indonesia. Indonesia is experiencing quite a difficult situation in dealing with the spread of the Corona virus (Covid-19). As of 26 April 2020, there have been 8,882 positive cases with 743 fatalities. The death rate in Indonesia is classified as very high which has reached $8.36 \%$, higher than the percentage of global mortality. The Indonesian government has implemented measures to deal with the Corona virus (Covid-19) outbreak, starting from social distancing, staying at home, working from home, spraying disinfectants, calling for the use of masks, to Large-Scale Social Restrictions (PSBB) through Government Regulation (PP) Number 21 of 2020 for regions that have high virus distribution. In addition, isolation both independently and in hospital isolation has also been implemented from the start for suspects infected with the virus. WHO standards for both the public and medical personnel have also been improved. But in reality, the spread of this plague has not been resolved and is still in a dangerous state.

The Corona virus pandemic (Covid-19) has threatened almost all aspects of human life. Almost none of the aspects of life are not negatively affected 
by this epidemic. Various aspects affected by the Corona virus (Covid-19) were initially only in the health aspect, continued in the social, religious, educational and of course economic aspects. Demand for goods and services decreased during this period (Özatay, \& Sak, 2020). This is a difficult thing for a developing country (Loayza \& Pennings, 2020), especially for countries with large populations and dominated by small-to-medium industries to support the economy like Indonesia. This is based on that small businesses medium becomes very brittle (fragile) during Covid-19 (Bartik et al., 2020). Oxford Analytica (2020) states that Indonesia and the Philippines are the worst affected countries in ASEAN in the economic sector. Under these circumstances, there is a demand that the economy must continue to run, mainly because of the very large population.

Governments in various countries basically have limited resources so they must be wise in managing and allocating their resources through certain policies so that they are sufficient (Didier et al., 2020). Hausmann (2020) states that policy making between countries will be different, especially in terms of the scope of policies due to different circumstances and conditions faced by each country. In line with this statement, constructive studies are urgently needed in order to keep the economy alive in Indonesia during the outbreak of this outbreak, by looking at the conditions and conditions faced by Indonesia.

The Indonesian economy is indeed dominated by Micro, Small and Medium Enterprises (MSMEs), where according to Kompas (2019), its contribution reaches $60.34 \%$ of the country's Gross Domestic Product. With limited community activities, business actors from various sectors experienced a large decline in sales turnover (Diesmadi \& Shaleh, 2020). Not a few business actors have temporarily stopped operating their business activities, at least until things return to normal. Business sustainability is certainly one thing that must be considered during this period (Bhattacharyya, 2020). This causes difficulties for business people, especially for MSMEs, which have limited resources and access to funding. This situation applies in various regions, including the city of Solo, which is dominated by the creative industry with the status of MSMEs.

Solo City has determined the status of an Extraordinary Situationas in other regions in dealing with the spread of the Corona virus (Covid-19) through the Decree of the Mayor of Surakarta Number
443.76 / 28 of 2020 concerning Determination of the Status of Corona Virus Disease (COVID-19) Extraordinary Events in Surakarta. As a region that applies social restrictions, the City of Solo has had a significant impact on the economy. Many business actors have temporarily closed their business operations due to the drastic decline in sales turnover, including the batik industry. In Solo, batik MSMEs is a mainstay for local government and society in improving the economy. There are as many as 167 batik MSMEs entrepreneurs in the city of Solo (Central Statistics Agency, 2019). BPS data (2019) also shows that batik MSMEs contribute greatly by becoming the second largest export commodity in the economy of Solo City after textiles. Two areas that are the center of the batik industry in this city include Kauman and Laweyanareas.producing and selling batik. The batik trading centers include Klewer Market, Beteng Trade Center and Solo Wholesale Center.

The majority of MSMEs rely on funding their businesses through credit taking steps from banks. Meanwhile, since the Corona virus (Covid-19) outbreak began in early March, all trade centers in Solo were quiet. As a result, their sales turnover fell dramatically and even there were no more sales so they decided to close for a while, at least until things returned to normal. With this kind of situation, business sustainability is threatened. On the one hand, MSMEs receive little or no income. On the other hand, they still have to pay installment fees and interest on loans they get from banks. Therefore, the Government of the Republic of Indonesia issued a credit relaxation policy during the period of the spread of the Corona virus (Covid-19) outbreak.

The credit relaxation policy issued by the government through the Financial Services Authority Regulation Number 11 / POJK.03 / 2020. This policy provides relief for bank debtors who are affected by the Corona virus (Covid-19), starting from lowering interest rates to temporarily delaying payments. This policy is expected to help MSMEs affected by the spread of the Corona virus (Covid-19) from bankruptcy. This policy was welcomed and gave a little hope and optimism for business people in order to maintain the sustainability of their business. Therefore, the responses, ideas and experiences of MSMEs business actors on policy implementation in maintaining their business continuity need to be studied in depth. This research focuses on analyzing 
the effectiveness of credit relaxation policies on the sustainability of MSMEs in order to understand, and to develop other policies related to MSMEs funding to encourage economy in particular in a similar situation.

The credit relaxation policy implemented in Indonesia is expected to help MSMEs in supporting their business sustainability. This is because small businesses tend to be more fragile during the Covid19 pandemic (Batrik et al., 2020). Basically, the government is indeed obliged to overcome the impact of the Covid-19 pandemic through certain policies to make it sufficient (Didier et al., 2020). With the Indonesian setting, as other countries also have their own different settings (Hausmann, 2020), a study of the implementation of policies implemented by the government is needed. With MSMEs as a relatively fragile part of the industry at this time, perception and evaluation they need to consider government policies, especially related to credit relaxation policies. Evidence is needed regarding the effect of credit relaxation policies in supporting the sustainability of MSMEs. Therefore, the formulation of the problem in the research is how the effect of the credit relaxation policy on the sustainability of the MSMEs Batik business in Solo during the Covid-19 period.

Based on the problem formulation described in the previous section, this study aims to examine the effect of the effectiveness of the credit relaxation policy on the business sustainability of Batik MSMEs in Solo City during the Covid-19 period. It is hoped that the implementation of this research can provide benefits and contributions to various parties related to the practice of developing the quality of financial statements as follows: (1) Contributing to the government in order to increase the effectiveness of the implementation of credit relaxation policies during the period of the spread of the Corona outbreak (Covid-19). (2) Assisting MSMEs in conveying their needs and funding problems during the period of the spread of the Corona outbreak (Covid-19). (3) Adding references and studies to the banking credit research literature, particularly during the disaster period in Indonesia.

\section{Micro, Small and Medium Enterprises (MSMEs)}

Micro, Small and Medium Enterprises (MSMEs) in Indonesia are regulated in Law Number 20 of 2008 concerning Micro, Small and Medium Enterprises Article 1. In this law, it is stated that:

a. Micro enterprises are productive businesses owned by individuals and / or individual business entities that meet the criteria of micro enterprises as stipulated in the law, namely that their assets are a maximum of IDR 50 million and a maximum turnover of IDR 300 million.

b. Small business is a productive economic business that stands alone, which is carried out by individuals or business entities that are not a subsidiary or branch of a company that is owned, controlled, or is a part, either directly or indirectly, of a medium or large business The criteria for small businesses as referred to in the law are asset value between Rp. 50 million to Rp. 500 million and a turnover of around Rp. 300 million to Rp. 2.5 billion.

c. Medium enterprises are productive economic enterprises that are independent, carried out by individuals or business entities that are not subsidiaries or branches of companies that are owned, controlled, or as part of, either directly or indirectly, with Small or Large Businesses with total assets. net or annual sales proceeds. The criteria to be classified as a medium-sized business are total assets ranging from IDR 500 million to IDR 10 billion and a turnover of IDR 2.5 billion to IDR 50 billion.

According to Bank Indonesia (2016), the development of Small and Medium Enterprises (SMEs) is essentially a shared responsibility between the government and society. From internal factors, MSMEs in Indonesia really need assistance in terms of capital. The government needs to expand a special credit scheme with conditions that are not burdensome for MSMEs, to help increase their capital, be it through the formal financial services sector, informal financial services sector, guarantee schemes, leasing and venture capital funds. In addition, by looking at the external factors faced by MSMEs, in the future efforts should be made to create a conducive business climate where the government can strive, among others, by seeking business peace and security as well as simplifying business licensing procedures, tax relief and so on.

\section{Credit Relaxation Policy}

Financial Services Authorityas the agency authorized in regulating the financial services industry is very concerned that the Corona virus pandemic (Covid-19) has a significant impact on the performance and capacity of banking debtors in paying their loan installments, including debtors 
micro, small and medium enterprises (MSMEs). This has the potential to affect economic growth. This also hampers the performance of the banking sector and the stability of the financial system in Indonesia. Therefore, OJK issued Regulation of the Financial Services Authority Number 11 / POJK.03 / 2020 concerning National Economic Stimulus as a Countercyclical Policy on the Impact of the Spread of Coronavirus Disease 2019 to encourage optimization of the banking intermediation function, maintain financial system stability, and support economic growth, an economic stimulus policy is required. as a countercyclical impact of the spread of Covid-19.

The POJK regulates that banks can implement policies that support the stimulus of economic growth for their debtors who are affected by the spread of Covid-19, including MSMEs debtors, while still paying attention to the principle of prudence. The debtors in question are debtors who have difficulty fulfilling their obligations to the bank because the debtor or debtor's business is affected by the spread of Covid-19, either directly or indirectly. Banks are expected to implement policies that support various sectors in the economy including: tourism, transportation, hotels, trade, processing, agriculture and mining. The stimulus policies that can be implemented by banks are:

a. Assessment of credit / financing / other provision of funds only based on the accuracy of principal and / or interest payments for credit / financing / other provision of funds with a ceiling of up to IDR 10 billion; and

b. Increasing the quality of credit / financing to become smooth after restructuring during the validity period of the POJK. This restructuring provision can be applied by the Bank regardless of credit / financing ceiling limits or the type of debtor.

The ways of restructuring credit / financing that can be carried out by banks as stipulated in the OJK regulations regarding asset quality assessment include, among others: (a) lowering interest rates; (b) extension of the period; (c) reduction of principal arrears; (e) reduction of interest arrears; (f) additional credit / financing facilities; and / or (g) credit / financing conversion to Temporary Equity Participation.

Banks can provide new credit / financing / provision of funds to debtors who have received special treatment in accordance with this POJK by determining the quality of credit / financing / other provision of funds carried out separately from the quality of credit / financing / other previous provision of funds.

\section{Hypothesis}

\section{Effect of Credit Relaxation Policy Effectiveness on Business Sustainability of BatikMSMEs in Solo during the Covid-19 Pandemic Period}

Governments in various countries are basically obliged to manage economic aspects during the Covid-19 pandemic period through certain policies (Didier et al., 2020). The industrial aspect is of course very important as an economic driver, with MSMEs in the Indonesian context.Indonesia through the Financial Services Authority Regulation Number 11 / POJK.03 / 2020 regulates economic stimulus during the Covid-19 period. In this policy, the credit relaxation policy is one that is implemented to maintain the sustainability of MSMEs (Diesmadi\&Saleh, 2020), considering that business continuity is an aspect that must be considered during this period (Bhattacharyya, 2020).

Countries in Europe have paid attention to the credit aspect during the Covid-19 pandemic period, where banks are expected to ease credit for their debtors, both households and industries so that they can go through this period without making their credit default (Alvarez, 2020). Various countries, namely Britain, the United States, New Zealand, Japan, Nigeria, South Korea and Canada, have also lowered interest rates to keep industrial businesses running (Ozili\&Arun, 2020). Baker \& Judge (2020) also marks the importance of extending credit to support the economy. In the context of Indonesia, to support its debtors during the Covid-19 period, OJK arranged for banks to implement lower interest rates, extension of term, reduction of principal arrears, reduction of interest arrears, additional credit / financing facilities; and / or, conversion of loans / financing becomes Equity Sementara.Dengan credit relief, diharapkanakan support the sustainability of SMEs in Indonesia Based on the above, the hypothesis is stated as follows:

$\mathrm{H}_{1}$ : The effectiveness of credit relaxation policy positively affects business continuity of MSMEs Batik in Solo during the Covid-19 Pandemic Period. 


\section{RESEARCH METHOD}

\section{Research Design}

This research is a causality study with the aim of testing the hypothesis. This study seeks to examine the effect of creditor relaxation policy on the sustainability of the MSMEs Batik business in Solo during the Covid-19 period.

\section{Population and Sample}

The population in this study were all batik MSMEs in the city of Solo. The sampling process uses themethodSnow-Ball Samplingin which one research sample will recommend other relevant people to become the next research sample until the required sample size is met (Sekaran\&Bougie, 2013).

\section{Research Data}

This research uses primary type data. This research data collection technique is carried out through a research questionnaire instrument from respondents. The questionnaire is a collection of questions or statements given to research subjects based on the theory that has been made. The data used in this study are primary data, namely data obtained from original sources specifically collected by researchers. The questionnaire was given to batik MSMEs in Surakarta who were the samples in this study.

\section{Research Instruments}

The research instrument is a measuring tool used by researchers to measure research data (Sekaran \& Bougie, 2013). The instrument used was a questionnaire with relevant statement items to describe the variables supported by previous research. In this study the measurement scale used is Likert.Scale Likertused to measure attitudes, opinions and perceptions of a person or group of people on a social phenomenon. Researchers used ascale Likert with four alternative answers, namely strongly agree, agree, disagree and strongly disagree. Alternative answers given to positive tone questions were assessed by consecutive scores: Strongly Disagree (1), Disagree (2), Neutral (3), Agree (4), Strongly Agree (5). In contrast, the alternative answers given to negative tone questions were assessed by consecutive scores: Strongly Disagree (5), Disagree (4), Neutral (3), Agree (2), Strongly Agree (1). There are also questions on the range of numbers classified on a Likert scale as follows: $0 \%$ to $20 \%$ (1), $21 \%$ to $40 \%$ (2), $41 \%$ to $60 \%$ (3), $61 \%$ to $80 \%$ (4), $81 \%$ to $100 \%$ (5).

\section{Variable Operational Definition}

As a causality study, the variables in this study consist of the dependent variable and the independent variable. This study also uses control variables. An explanation of each research variable is presented as follows:

\section{a. Dependent Variable}

The dependent variable in this study is the sustainability of MSMEs Batik in Solo. This variable describes the perceptions of the Batik MSMEs players in the city of Solo on the continuity of their business due to the Corona virus (Covid-19) pandemic. The dependent variable in this study was measured using 9 questions which were realized from the questionnaire. For each question item, the measurement was carried out with a Likert scale of 1-5. Answers to all questions will be averaged to determine the value of the variable.

\section{b. Independent Variable}

The independent variable in this study is the effectiveness of the credit relaxation policy during the Corona virus pandemic (Covid-19). This variable describes the perceptions of the Batik MSMEs actors in Solo on the effectiveness of the credit relaxation policy from their experiences. The independent variable in this study was measured using 9 questions which were realized from a questionnaire. For each question item, the measurement was carried out with a Likert scale of 1-5. Answers to all questions will be averaged to determine the value of the variable.

\section{c. Control Variables}

This study uses control variables to accommodate other influences that are outside the research independent variables. The control variables used in this study are the financial impact of the Covid-19 pandemic, and the profile of MSMEs. Explanation and measurement of control variables are presented as follows:

\section{Financial impact of the Covid-19 Pandemic}

This variable illustrates the perceptions of the Batik MSMEs players in the City of Solo regarding the impact of the spread of the Covid19 pandemic on their business finances. This variable is measured using 3 questions which are realized from the questionnaire. For each question item, the measurement was carried out with a Likert scale of 1-5. Answers to all 
questions will be averaged to determine the value of the variable.

\section{Method of Analysis}

\section{a. Descriptive Statistics}

Descriptive statistics are statistical tools used to present quantitative descriptions of research objects in a manageable form without making analyzes and conclusions. Descriptive statistics help in simplifying large amounts of data. Each descriptive statistic reduces many explanations of the data to a simpler summary. In general, descriptive statistics use univariate analysis with the observation of one variable at a time.

1) Distribution of data as represented by a frequency distribution;

2) Thecentral tendency as represented by the mean, median and mode;

3) Dispersion of data as represented by the standard deviation.

\section{b. Research Instruments Testing}

In research, data has a very important position because the data is what is being studied and functions as a means of proving a hypothesis. Therefore, whether the data is correct or not will determine the quality of the research results. On the other hand, whether the data is correct or not depends on whether the data collection instruments are good or not. A good instrument (questionnaire) must meet two prerequisites, valid and reliable.

\section{1) Validity Test}

The validity test of a tool used to measure research instruments that show the validity or validity of a questionnaire (Ghozali, 2013). This testing to determine whether it is significant or insignificant by comparing the calculated $r$ value with the $r$ table. Thus the decision provisions are as follows:

a) If $r_{\text {calculated }}>r_{\text {table }}$ at the $5 \%$ significance level, the measuring instrument or research instrument used is valid.

b) If $r_{\text {calculated }} \leq r_{\text {tableat }}$ the $5 \%$ significance level, then the measuring instrument or research instrument used is invalid.

\section{2) Reliability Testing}

Reliability test is a tool for measuring a questionnaire which is an indicator of a variable that shows the extent to which a measurement is unbiased (error free) and therefore

guarantees

consistent measurements across time and across various items in the instrument (Ghozali, 2013). Statement items are said to be reliable or reliable if a person's answer to the statement is consistent. Measuring the reliability of statement items by distributing a questionnaire to the respondent once, then the results of the score are measured for the correlation between the answer scores on the same statement items. To test the reliability or reliability of measuring instruments or instruments in this study, the Cronbach Alpha coefficient $(\alpha)$ was used. A variable is said to be reliable if it gives a Cronbach Alpha $(\alpha)$ value $>0.60$. The reliability coefficient shows the quality of the entire data collection process of a study. Then the results of the calculation of $r$ are interpreted by the reliability level of the correlation coefficient (Ghozali, 2013).

Tabel 1. Interpretation Value ofr

\begin{tabular}{|l|l|}
\hline \multicolumn{1}{|c|}{ r Value } & \multicolumn{1}{c|}{ Interpretation } \\
\hline 0,800 to 1,000 & Very high \\
\hline 0,600 to 0,799 & High \\
\hline 0,400 to 0,599 & Fairly High \\
\hline 0,200 to 0,399 & Low \\
\hline 0,000 to 0,199 & Very low \\
\hline
\end{tabular}

\section{Classic Assumption Test}

\section{a. Normality test}

The normality test aims to test whether in the regression model, confounding or residual variables have a normal distribution (Ghozali, 2013). If it is normality, the residuals will be normally distributed and independent. The normality test used in this study is the Kolmogorov-Smirnov test.The data requirements are normal if the probability is above 0.05 . In addition to this analysis is graphical analysis, which is one of the easiest ways to view normality. This can be done by looking at a normalgraph probability plot that compares the cumulative distribution of the normal distribution. The normal distribution will form a straight diagonal line, and the plot of residual data will be compared with the diagonal line.

\section{b. Multicollinearity Test}

The multicollinearity test aims to test whether the regression model finds a correlation between 
independent variables. A good regression model should not have a correlation between independent variables (Ghozali, 2013). This classic assumption test can be done by regressing the analysis model and correlating between independent variables. by using the Variance Inflation Factor (VIF).If VIF is greater than 10 and the tolerance value is less than 0.01 , multicollinearity occurs.

\section{c. Heteroscedasticity Test}

This test aims to test whether in the regression model there is an inequality of variants from one observation residual to another (Ghozali, 2011). If the residual variance from one observation to another is constant, it is called homoscedasticity and if it is different it is called heteroscedasticity. One way to test the presence or absence of heteroscedasticity is by using the Glejser test. The Glejser test is performed by regressing between the independent variables and their residual absolute values. If the significance value between the independent variables and the absolute residual is more than 0.05 , heteroscedasticity does not occur.

\section{Multiple Linear Regression Analysis}

Hypothesis testing in this study was carried out through multiple regression analysis. Basically, multiple regression analysis tests the dependence of the dependent variable with one or more independent variables with the aim of estimating and / or predicting the population mean or average value of the dependent variable based on the known value of the independent variable. regression is a coefficient for each independent variable. This coefficient is obtained by predicting the value of the dependent variable with an equation, which is as follows:

\section{KEBER $=\alpha+b_{1}$ RELAK $+b_{2}$ DAMPKEU $+e$}

Description:

$\begin{array}{ll}\text { KEBER } & \text { : Business Continuity of MSMEs } \\ \alpha & : \text { Constants } \\ \mathrm{b}_{1}-\mathrm{b}_{6} & : \text { Coefficient of Regression } \\ \text { RELAK } & : \text { Effectiveness ofCredit Relaxation } \\ & \text { Policy } \\ \text { DAMPKEU : Financial Impacts on MSMEs from } & \text { Covid-19 } \\ e & : \text { Error }\end{array}$

Several important components of the multiple linear regression analysis test results need to be studied to test the acceptance / rejection of the hypothesis. Some of these components include:

\section{a. Test $\mathbf{R}^{\mathbf{2}}$ (coefficient of determination)}

In essence, the coefficient of determination is used to measure how far the model's ability to explain the variationof independen variable. Coefficientdetermination value isbetween zero andone.If $\mathrm{R}^{2}$ value small,the ability of independent variables in explaining the variation of the dependent variable so limited. The value which approaching one has meaning that the independent variables provide almost all the information needed to predict variations in the dependent variable (Ghozali, 2013).

\section{b. F Statistical Test (Model Fit)}

The F statistical test is used to determine whether the independent variables together (simultaneously) have a significant effect on the dependent variable. The degree of confidence used was 0.05 (Ghozali, 2013).

The hypothesis that will be used in this study is: $\mathrm{H}_{0}: \beta_{1}=\beta_{2}=\beta_{3}=0$, The independent variables do not have a significant effect together on the dependent variable.

$H_{0}: \beta_{1}=\beta_{2}=\beta_{3} \neq 0$, The independent variables have a significant effect together on the dependent variable.

The basis for decision making (Ghozali, 2013):

1) Comparing the calculated $F$ value with $F$ table

If Ftable> Fcalculated, then $\mathrm{H}_{0}$ is accepted and $\mathrm{H}_{\mathrm{a}}$ is rejected.

If Ftable $\leq$ Fcalculated, then $\mathrm{H}_{0}$ is rejected and $\mathrm{H}_{\mathrm{a}}$ is accepted.

2) Using the probability figure of significance If the significance probability $>0.05$, then $\mathrm{H}_{0}$ is accepted and $\mathrm{H}_{\mathrm{a}}$ rejected.

If the significance probability $\leq 0.05$, then $\mathrm{H}_{0}$ is rejected and $\mathrm{H}_{\mathrm{a}}$ accepted.

\section{c. T statistical test (Partial Regression Test)}

The $t$ statisticaltestor test of significance is used to determine the independent variable on the dependent partially (individually), the degree of significance used is 0.05 (Ghozali, 2013).

The hypothesis that will be used in this test is: 
$\mathrm{H}_{0}$ : bi $=0$, The independent variables $\left(\mathrm{X}_{1}, \mathrm{X}_{2}\right.$, $\mathrm{X}_{3}$ ) do not have a significant effect on the dependent variable (Y).

$\mathrm{H}_{1}$ : bi $\neq 0$, The independent variables $\left(\mathrm{X}_{1}, \mathrm{X}_{2}\right.$, $X_{3}$ ) have a significant effect on the dependent variable $(\mathrm{Y})$.

The basis for decision making (Ghozali, 2013):

1) Comparing the calculated $t$ value with $t$ table. If $\mathrm{t}$ table> $\mathrm{t}$ calculated, then $\mathrm{H}_{0}$ is accepted and $\mathrm{H}_{\mathrm{a}}$ is rejected.

If $\mathrm{t}$ table $\leq \mathrm{t}$ calculated, then $\mathrm{H}_{0}$ is rejected and $\mathrm{H}_{\mathrm{a}} \mathrm{is}$ accepted.

2) Using the probability of significance.

If the significance probability value> 0.05 , then $\mathrm{H}_{0}$ is accepted and $\mathrm{H}_{\mathrm{a}}$ is rejected.

If the significance probability value $\leq 0,05$, then $\mathrm{H}_{0}$ is rejected and $\mathrm{H}_{\mathrm{a}}$ is accepted.

\section{TESTING RESULTS}

\section{a. Validity Test}

This test tool is used to measure the level of validity and invalidity of a question item from the questionnaire. In this study the value of $\mathrm{N}=43, \mathrm{df}=$ $\mathrm{N}-2=43-2=42$ with the table correlation coefficient used is $5 \%$ or 0.05 so that the rvalueistable 0.3008 . To provide an overview of the validity test in this study, it is shown in the table as follows:

1) Effectiveness of Credit Relaxation Policy

The results of validity testing can be seen in table 2 as presented below:

Table 2

Effectiveness of Credit Relaxation Policy (RK Policy)

\begin{tabular}{|c|c|c|c|}
\hline Question & $\mathrm{r}_{\text {count }}$ & $\mathrm{r}_{\text {table }}$ & Description \\
\hline Kebijakan RK 1 & 0,770 & 0,3008 & valid \\
\hline Kebijakan RK 2 & 0,807 & 0,3008 & valid \\
\hline Kebijakan RK 3 & 0,757 & 0,3008 & valid \\
\hline Kebijakan RK 4 & 0,708 & 0,3008 & valid \\
\hline Kebijakan RK 5 & 0,337 & 0,3008 & valid \\
\hline Kebijakan RK 6 & 0,823 & 0,3008 & valid \\
\hline Kebijakan RK 7 & 0,756 & 0,3008 & valid \\
\hline Kebijakan RK 8 & 0,806 & 0,3008 & valid \\
\hline
\end{tabular}

Source: Primary Data SPSS 2020

Based on table 2, it shows that all question items in the Credit Relaxation Policy Effectiveness variable are declared valid because $r_{\text {calculated }}$ of each question item is greater than $r_{\text {table }}$ with

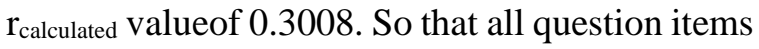
in the variable on the effectiveness of the credit relaxation policy can be used as a research instrument.

2) Financial Impact of the Covid-19 Pandemic The results of validity testing can be seen in table 3 as presented below:

Table 3

Financial Impact of the Covid-19 Pandemic

\begin{tabular}{|c|c|c|c|}
\hline Question & $\mathrm{r}_{\text {count }}$ & $\mathrm{r}_{\text {table }}$ & Description \\
\hline Dam Keu 1 & 0,812 & 0,3008 & valid \\
\hline Dam Keu 2 & 0,603 & 0,3008 & valid \\
\hline Dam Keu 3 & 0,739 & 0,3008 & valid \\
\hline
\end{tabular}

Source: Primary Data SPSS 2020

Based on table 3, it shows that all question items in the Financial Impact variable of the Covid-19 Pandemic are declared valid because the $r_{\text {calculated }}$ of each question item is greater than the $r_{\text {table }}$ with $r_{\text {calculated }}$ valueof 0.3008 . So that all question items in the variable on the effectiveness of the credit relaxation policy can be used as a research instrument.

3) Sustainability of MSMEs in the Future (MSMEs) The results of the validity test can be seen in table 4 as presented below:

Table 4

Sustainability of MSMEs in the Future

\begin{tabular}{|c|c|c|c|}
\hline Question & $\mathrm{r}_{\text {count }}$ & $\mathrm{r}_{\text {table }}$ & Description \\
\hline UMKM 1 & 0,379 & 0,3008 & valid \\
\hline UMKM 2 & 0,686 & 0,3008 & valid \\
\hline UMKM 3 & 0,480 & 0,3008 & valid \\
\hline UMKM 4 & 0,373 & 0,3008 & valid \\
\hline UMKM 5 & 0,318 & 0,3008 & valid \\
\hline UMKM 6 & 0,596 & 0,3008 & valid \\
\hline UMKM 7 & 0,435 & 0,3008 & valid \\
\hline UMKM 8 & 0,710 & 0,3008 & valid \\
\hline UMKM 9 & 0,551 & 0,3008 & valid \\
\hline
\end{tabular}

Source: Primary Data SPSS 2020

Based on table 4, it shows that all question items in the variable of MSME Sustainability in the Future are declared valid because the $\mathrm{r}_{\text {calculated }} \mathrm{of}$ each question item is greater than the $r_{\text {table }}$ with

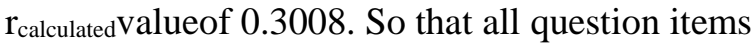
in the variable on the effectiveness of the credit relaxation policy can be used as a research instrument. 


\section{b. Reliability Test}

The results of validity testing can be seen in table 5 as presented below:

Table 5

Reliability Test Results

\begin{tabular}{|c|c|c|c|}
\hline Variable & $\begin{array}{c}\text { Cronbch's } \\
\text { Alpha }\end{array}$ & $\begin{array}{c}\text { Level Cronbach's } \\
\text { Alpha }\end{array}$ & Description \\
\hline Relak & 0,875 & 0,600 & Reliable \\
\hline DamKeu & 0,610 & 0,600 & Reliable \\
\hline Keber & 0,636 & 0,600 & Reliable \\
\hline
\end{tabular}

Source: Primary Data SPSS 2020

Reliability test results as shown in table 5 indicate that the Cronbach's Alpha value is greater than 0.600, it can be concluded that the research variable instrument is reliable to be used as a variable measuring tool. This shows that each question item used in the questionnaire will obtain consistent data.

\section{c. Descriptive Statistics}

Table 6

Descriptive Statistics

\begin{tabular}{|c|c|c|c|c|c|}
\hline & $\mathrm{N}$ & Min & Max & Mean & $\begin{array}{c}\text { Std. } \\
\text { Deviation }\end{array}$ \\
\hline Relak & 43 & 12 & 39 & 26.07 & 5.974 \\
\hline DamKeu & 43 & 5 & 15 & 11.37 & 2.507 \\
\hline Keber & 43 & 23 & 42 & 33.49 & 4.672 \\
\hline $\begin{array}{c}\text { Valid N } \\
\text { (listwise) }\end{array}$ & 43 & & & & \\
\hline
\end{tabular}

Source: Primary Data SPSS 2020

d. Classical Assumption Test

1) Normality Test

Table 7

Normality Test Results

\begin{tabular}{|c|c|}
\hline Description & $\begin{array}{c}\text { Unstandardized } \\
\text { Residual }\end{array}$ \\
\hline Kolmogorov-Smirnov Z & 0,070 \\
\hline Asymp. Sig. (2-tailed) & 0,200 \\
\hline
\end{tabular}

Source: Primary Data SPSS 2020

Based on the normality test results above, it is found that the value of Asymp. Sig shows a value of 0.200 or $20 \%$, this indicates that the data has been normally distributed because the value is greater than 0.05 or $5 \%$.
2) Multicollinearity

Table 8

Multicollinearity Test Results

\begin{tabular}{|c|c|c|c|c|}
\hline \multicolumn{5}{|c|}{ CollinearityStantics } \\
\hline Model & Variable & Tolerance & VIF & Description \\
\hline \multirow{3}{*}{} & \multicolumn{4}{|c|}{ Constant } \\
\cline { 2 - 5 } & Relak & 0,96 & 1.03 & $\begin{array}{c}\text { Multicollinearit } \\
\text { y does not } \\
\text { occur }\end{array}$ \\
\cline { 2 - 5 } & DamKeu & 0,96 & 1.03 & $\begin{array}{c}\text { Multicollinearit } \\
\text { y does not } \\
\text { occur }\end{array}$ \\
\hline
\end{tabular}

Source: Primary Data SPSS 2020

Based on the multicollinearity test results above, it shows that there are no independent variables that have a VIF value below 10 and a tolerance value that has a value above 0.01 . This means that the model is free from multicolinearities.

3) Heteroscedasticity

Table 9

Reliability Test Results

\begin{tabular}{|c|c|c|c|c|}
\hline Model & Variable & $\mathrm{T}$ & Sig & Description \\
\hline \multirow{1}{*}{1} & (Constant) & 1.43 & 0,15 & \\
\cline { 2 - 5 } & $\begin{array}{c}\text { Kebijakan } \\
\text { RK }\end{array}$ & -0.75 & 0,45 & $\begin{array}{c}\text { There is no } \\
\text { heteroscedasticity }\end{array}$ \\
\cline { 2 - 5 } & Dam Keu & 0.78 & 0,43 & $\begin{array}{c}\text { There is no } \\
\text { heteroscedasticity }\end{array}$ \\
\hline
\end{tabular}

Source: Primary Data SPSS 2020

Based on the heteroscedasticity test, it shows that all independent variables have a value above 0.05 or $5 \%$. This means that the regression model is free from heteroscedasticity problems.

e. Multiple Linear Regression Analysis and Hypothesis Testing

1) Hypoesis Test

Hypothesis testing in this study uses multiple linear regression test to test the independent variable against the dependent variable and the results of the test are as follows:

Tabel 10

Hypothesis Testing

\begin{tabular}{|c|c|c|c|c|l|}
\hline Model & Variable & $\begin{array}{c}\text { Coeffici } \\
\text { ents }\end{array}$ & $\mathrm{T}$ & Sig. & Description \\
\hline 1 & (Constant) & 33,66 & 8,39 & 0.00 & \\
\cline { 2 - 6 } & $\begin{array}{c}\text { Kebijakan } \\
\text { RK }\end{array}$ & 0,23 & 2,05 & 0,04 & Signifikan \\
\hline
\end{tabular}


Jurnal Akuntansi dan Pajak, 21 (02), 2021, 459

\begin{tabular}{|c|c|c|c|c|c|}
\hline Model & Variable & $\begin{array}{c}\text { Coeffici } \\
\text { ents }\end{array}$ & $\mathrm{T}$ & Sig. & Description \\
\hline & Dam Keu & $-0,56$ & $-2,03$ & 0,04 & Signifikan \\
\hline & $\mathrm{F}$ hitung & & & 3,55 & \\
\hline & $\mathrm{R} 2$ & & & 0,15 & \\
\hline & Adjusted R2 & & & 0,10 & \\
\hline & Sig. & & & 0,03 & \\
\hline
\end{tabular}

Source: Primary Data SPSS 2020

Theresults of hypothesis testing in showing the multiple linear regression equation are as follows:

\section{$\mathrm{UMKM}=33.665+$ 0,238Relak - 0,560 Dam $\mathrm{Keu}+\varepsilon$}

2) F Test

The $\mathrm{F}$ test results shown in table 10 indicate that the calculated $F$ value is 3.551 with a significant level of 0.03 less than 0.05 , it can be concluded that the variable of the credit relaxation policyeffectiveness and the financial impact of the Covid-19 pandemic shows that the model is fit.

3) $\mathrm{R}^{2}$ Test

The coefficient of determination (Adjusted $\mathrm{R}$ square) as shown in table 10 shows a value of 0.108 so it can be interpreted that the independent variables, namely the effectiveness of credit relaxation policies and the financial impact of the Covid-19 pandemy, can explain the dependent variable, namely the sustainability of MSMEs in the future $10.8 \%$, then the remaining $89.2 \%$ is influenced by variables outside the model.

4) $\mathrm{T}$ Test

The results of the $t$ test are as shown in Table 10 The criteria set if the significance value is less than 0.05 , the hypothesis is accepted:

a) The significancevalue is 0.04 , which means that the variable effectiveness of the credit relaxation policy affects the sustainability of MSMEs in the future.

b) The significance value is 0.04 , which means that the financial impact variable of the Covid-19 pandemic has an effect on the sustainability of MSMEs in the future.

\section{Discussion}

Effect of Credit Relaxation Policy Effectiveness on Business Sustainability of Batik MSMEs in Solo during the Covid-19 Pandemic

\section{CONCLUSION}

a. Limitations of the Study: The limited research sampling was only 43 samples, so it was felt that it did not support the information in this study.

b. Research Suggestions:

1) Further research can add independent variables other than those in this study, such as MSME profile variables which can explain the amount of assets, level of debt, etc.

2) Future research is expected to increase the research sample so that the results obtained from further research can be compared.

\section{REFERENCES}

Álvarez, M. C. (2020).Covid-19 credit guarantees in the eurozone. Spanyol: Funcas. Dapat diakses pada http://www.funcas.es/func aseurope/pdf/080420_CovidMeasures_Carrion.p df

Badan Pusat Statistik (2019). Kota Surakarta dalam Angka 2018. Surakarta: Badan Pusat Statistik.

Baker, T., \& Judge, K. (2020). How to Help Small Businesses Survive COVID-19. Columbia Law and Economics Working Paper, (620).

Bank Indonesia (2016). Profil Bisnis Usaha Mikro, Kecil dan Menengah (UMKM).Jakarta: Bank Indonesia dan Lembaga Pengembangan Perbankan Indonesia.

Bartik, A. W., Bertrand, M., Cullen, Z. B., Glaeser, E. L., Luca, M., \& Stanton, C. T. (2020). How are small businesses adjusting to COVID-19? Early evidence from a survey (No. w26989). National Bureau of Economic Research.

Bhattacharyya, R. (2020). COVID-19 Pandemic: Business Continuity Checklist.Dapat diakses pada https://conservancy.umn.edu/bitst ream/handle/11299/212334/Business\%20Contin uity\%20Checklist\%20FINAL-editEP2020.04.09.pdf?sequence $=1$

Blanchard, O. (2020). What It Will Take to Save the Economy from COVID-19. Peterson Institute for International Economics, Washington, DC.

Budiyono, Pawar-Hole, S., Hole, Y., \&Bhaskar, M.P., (2020). Global market challenges and their impact on businesses. International Journal of Control and Automation 13(2). 7-17.

Cucinotta, D., \& Vanelli, M. (2020). WHO declares COVID-19 a pandemic. Acta bio-medica: Atenei Parmensis, 91(1), 157-160. 
Didier, T., Huneeus, F., Larrain, M., \& Schmukler, S. L. (2020). Financing Firms in Hibernation During the COVID-19 Pandemic. Research \& Policy Brief No.30, World Bank Group.

Disemadi, H. S., \& Shaleh, A. I. (2020). Banking credit restructuring policy amid COVID-19 pandemic in Indonesia. Jurnal Inovasi Ekonomi, 5(3).

Ghozali, I. (2013). Aplikasi Analisis Multivariate dengan Program SPSS. Semarang:Universitas Diponegoro

Hausmann, R. (2020). The Macroeconomic Implications of COVID-19 in our Partner Countries. Harvard University. Dapat diakses pada Centre for Development and Enterprise.

Loayza, N. V., \& Pennings, S. (2020). Macroeconomic policy in the time of covid-19: A primer for developing countries.Presentation, World Bank Group.

Miller, M., Bastagli, F., Hart, T., Raga, S., Mustapha, S., Papadavid, P., ... \& te Velde, D. W. (2020). Financing the coronavirus response in subSaharan Africa. Working paper 579, Overseas Development Institute (ODI). Dapat diakses pada https://www.odi.org/sites/odi.org.uk/files/resour ce-

documents/coronavirus_working_paper_0.pdf
Oxford Analytica. (2020). South-east Asia needs external help to handle COVID-19. Emerald Expert Briefings, (oxan-db).

Özatay, F., \& Sak, G. (2020). What Can We Do to Manage the Economic Consequences of COVID19?.TEPAV Policy Note, (202006).

Ozili, P. K., \& Arun, T. (2020). Spillover of COVID19: impact on the Global Economy. SSRN Paper 3562570.

Pemerintah Kota Surakarta (2020) Keputusan Walikota Surakarta Nomor 443.76/28 Tahun 2020 tentang Penetapan Status Kejadian Luar Biasa Corona Virus Disease (COVID-19) di Kota Surakarta.

Republik Indonesia (2020). Peraturan Pemerintah (PP) Nomor 21/2020 tentang Pembatasan Sosial Berskala Besar (PSBB).

Sekaran, U., \& Bougie, R. (2013). Research Methods for Business. Edisi enam. Jakarta: Salemba Empat. 